\title{
A Model of Intensification of Dairy Production as an Alternative for the Modernization of Family Farming in the Tropics
}

\author{
César Otaviano Penna Júnior (Corresponding author) \\ Federal Institute of Education, Science and Technology of Espírito Santo (IFES) campus \\ Alegre, Alegre, Espírito Santo, Brazil. \\ Tel: +552835641800 E-mail: copenna@ifes.edu.br

\section{Rogério Figueiredo Daher} \\ State University of Nortern of Rio de Janeiro Darcy Ribeiro (UENF), Campos dos \\ Goytacazes, Rio de Janeiro, Brazil. Tel: +55 2227486019 E-mail: rogdaher@ uenf.br
}

\section{Gercílio Alves de Almeida Júnior}

Federal University of Espírito Santo (UFES) campus Alegre, Alegre, Espírito Santo, Brazil. Tel: +55 2835528992 E-mail: gercilio.almeida@ufes.br

\section{Paulo Marcelo de Souza}

State University of Nortern of Rio de Janeiro Darcy Ribeiro (UENF), Campos dos Goytacazes, Rio de Janeiro, Brazil. Tel: +55 2227486019 E-mail: pmsouza@uenf.br

\section{Niraldo José Ponciano}

State University of Nortern of Rio de Janeiro Darcy Ribeiro (UENF), Campos dos Goytacazes, Rio de Janeiro, Brazil. Tel: +55 2227486019 E-mail: njponciano@gmail.com

\section{Ismail Ramalho Haddade}

Federal Institute of Education, Science and Technology of Espírito Santo (IFES) campus Santa Tereza, SantaTereza, Espírito Santo, Brazil. Tel: +55 2732597878 E-mail: ihaddade@gmail.com 
Ivan Jannotti Wendling

Federal University of Espírito Santo (UFES) campus Alegre, Alegre, Espírito Santo, Brazil. Tel: +55 2835528992 E-mail: ivanwendling@ hotmail.com

\title{
Bruna Rafaela da Silva Menezes
}

Federal Rural University of Rio de Janeiro (UFRRJ), Seropédica, Rio de Janeiro, Brazil. Tel: +55 2126822915 E-mail: brunarafamenezes@hotmail.com

\begin{abstract}
Alexandre Gomes de Souza
Postgraduate Program of Agricultural Science and Technology Center, State University of Nortern of Rio de Janeiro Darcy Ribeiro (UENF), Campos dos Goytacazes, Rio de Janeiro, Brazil. Tel: +55 2227486019 E-mail: alexandre.souza.agronomo@gmail.com

\section{Raiane Mariani Santos}

Postgraduate Program of Agricultural Science and Technology Center, State University of Nortern of Rio de Janeiro Darcy Ribeiro (UENF), Campos dos Goytacazes, Rio de Janeiro,

Brazil. Tel: +55 2227486019 E-mail: raianemarianisantos@gmail.com
\end{abstract}

Received: Feb. 3, 2020

doi:10.5296/jas.v8i2.16680
Accepted: Feb. 24, 2020 Published: Mar. 16, 2020

URL: https://doi.org/10.5296/jas.v8i2.16680

\begin{abstract}
Dairy farming is an activity of great socioeconomic relevance for family farming in Brazil, but is still characterized by low productivity, low technology employed, and low remuneration. The objective of this article is to verify how the indicators of technological intensification were aligned with gains in productivity indicators based on an irrigated grazing system under intermittent stocking, in a typical family farm in the south region of the Espírito Santo state. The farm from which data were collected was conveniently selected for having been monitored for 42 months, a period when the technological transition in a production model was occurred. The intermittent stocking management in the irrigated tropical pasture, in a module of 0.86 ha of Mombaça grass, has led to an increase in animal productivity (from 16 to 23 animal units per hectare), labor (96 liters of milk per family farming labor per day), and land indicators (from 219 to 349 liters of milk per hectare per day), but the increase in the scale of production is a limiting factor for competitiveness in the present case study. The proposed intensification model can become a feasible option for the
\end{abstract}


modernization of dairy farming in tropics.

Keywords: performance indicators, intermittent stocking, technical assistance and rural extension, animal data

\section{Introduction}

In the economic development process, there are changes in the way agricultural products are produced and destined for sale because of the growing technical-economic integration and subordination of the primary sector to the urban-industrial sectors (BACCARIN, 2011).

In this way, the current scenario of global agribusiness points to a constant need to evaluate the efficiency of production systems in any agricultural activity. Historically and globally, there has been a trend towards a loss in the power of exchange between agricultural products and their main production inputs, pressured by the ex-ante and ex-post links to rural properties. The transfer of income to the more organized sectors of the production chains has required rural producers to overcome the efficiency of using productive resources and obtaining scale to, at least, maintain the profitability of their production systems. This trend has been excluding thousands of producers in different agricultural activities, especially those with low capitalization levels, such as family farming (FF), which have limited investment capacity.

Poor management control, especially in FF, affects performance and financial results because the producer does not have information that could be used to make important decisions, which undermines strategic planning and activity management (SCHMOELLER et al., 2017) as in the case of the family dairy farming in Brazil, where the historical analyzes of the modernization of this sector suggest that the logic of development is incompatible with the viability of the activity. The current issue has been to oppose the future of FF to the process of rural modernization, as if one excludes the other (BUAINAIN et al., 2003).

Oliveira et al. (2016) highlighted there is a further need to expand knowledge regarding the dairy supply chain and farm and animal indicators that enable a better understanding of milk production systems. Moreover, as Silva et al. (2015) stated, with appropriate technical follow-up, dairy farming has the potential to be more viable performance indicators are monitored, considering that they help the decision-making process by means of identifying the interactions of many variables that interfere in production systems.

Indicators that allow comparing the effect of technology application on different farms are animal productivity, labor productivity and land productivity, which are directly impacted when the efficiency of productive resources is improved (RESENDE et at., 2012).

However, Schmoeller et al. (2017) warned that the number of dairy farmers who are in a position to analyze, plan and strategically conduct the activity is small. Therefore, the rural extensionist takes the lead in identifying the appropriate technologies for each production system, which is a determining factor in the success of technology generation and technology transfer (SILVA et al., 2015). This is also stated by Riet-Correa et al. (2013), that pointed the farmers generally accept the deployment of new technologies, as long as they are gradually 
deployed and appropriate to the systems, these authors also asserted that only with permanent and multidisciplinary technical assistance can limiting factors of a production system can be minimized.

According to Chambela Neto et al. (2018), the change of a reality in the Brazilian dairy farming, when animal productivity falls short of what is needed for the expected profit, involves the adoption of technologies such as soil acidity correction, fertilization and irrigation of pastures, as well as the reduction of areas and intensification, pasture production through strategic fertilization, the adoption of intermittent stocking management, the genetic improvement of the herd and, in some situations, the exchange of forage species.

Camargo (2009) suggested intensive pasture management with tropical forages as an efficient land use alternative, as it allows the production of large amounts of forage per area, combined with a satisfactory nutritional value of this forage. Thus, advances in research with tropical forage plants, despite the significant morphological variation of species of productive or economic interest, the different grazing sites and methods employed, the idealization and formulation of grazing management strategies become a real alternative for the production efficiency of livestock systems in tropical pastures (DA SILVA \& NASCIMENTO Jr., 2007).

Because of these aspects, the technology of milk production intensification by intermittent stocking in the irrigated tropical pasture has become an option for FF in mountainous regions, who aim at combining high productivity levels of their productive resources with a scale of production that enables competing with alternative agricultural activities. However, milk production on pasture demands a correct understanding and manipulation regarding the complex interaction among soil, plant, climate, animal, and human so that the production system can meet results within planned expectations.

\subsection{Research Question and Objectives}

This exploratory study sought to verify how the indicators of technological intensification were in line with benefits in productivity indicators, providing information on the effects of the intensification process on dairy farming in a tropical region.

As such, this article aims at responding to the following research question: By providing adequate technical support, does a dairy farming system under intensive tropical pasture management make it possible for FF to become competitive in the dairy supply chain?

In this way, the objective of this article is to verify how the indicators of technological intensification were aligned with gains in productivity indicators based on an irrigated grazing system under intermittent stocking, in a typical property of FF in the south region of the Espírito Santo state.

\section{Materials and Methods}

\subsection{Case Study Characterization}

The farm studied is located in the municipality of Alegre, state of Espírito Santo, Brazil, with geographic coordinates $20^{\circ} 37^{\prime} 48.6^{\prime \prime}$ south latitude and 41 $32^{\prime} 51.9^{\prime \prime}$ west longitude and is 
characterized by being a mountainous region of the south of the state. The dairy farming is the main economic activity, with the family labor force (FLF) composed of the owners (spouses), and conveniently selected for having been monitored in two production cycles, from March 2011 to February 2012 and from January to December 2013, a period in which there was a technological transition from a low-level technological production model, considered traditional in the region, to a production model enhanced by the adoption of technologies, occurred.

\subsection{Technical Assistance and Rural Extension Actions}

The decision was made to work with the intensified production model, adopting tropical pasture management as the productive base. To this end, an area of 0.86 ha of Mombaça grass (Panicum maximum Jacq cv. Mombaça) was recovered. After soil analysis, acidity was corrected, and organic and chemical fertilization of the area was carried out. A drip sprinkler irrigation system was implemented, and the area was divided into 25 paddocks with an electric fence. Management of the grass was based on its morphophysiological responses according to the light interception methodology mentioned by Da Silva \& Nascimento Jr. (2007), consisting of an occupation period that ranged from 0.5 to 1.0 day and a rest period between 13 and 26 days, depending on climate variations over the year. The lactating cows received individually concentrated feed in the proportion of $1.0 \mathrm{~kg}$ of concentrated feed to 3.0 liters of milk produced and were supplemented with sugar cane with $1 \%$ urea.

\subsection{Farm and Animal Indicators}

Chart 1 depicts the zootechnical indicators adopted to evaluate the production system and its calculation methods.

Chart 1. Farm and animal indicators used to assess the efficiency of the production system adopted in the case study.

\begin{tabular}{|l|l|l|}
\hline \multicolumn{1}{|c|}{ Item } & \multicolumn{1}{|c|}{ Unit } & \multicolumn{1}{c|}{ Description } \\
\hline \multicolumn{1}{|c|}{ Area } & \multicolumn{1}{|c|}{ Hectare (ha) } & Area for dairy farming \\
\hline Total Production & Liter (L) & Liters of milk in 12 months \\
\hline $\begin{array}{l}\text { Lactation cows } \\
\text { (LC) }\end{array}$ & $\%$ & $\begin{array}{l}\text { Number of lactation cows in relation to total } \\
\text { cows in the herd }\end{array}$ \\
\hline $\begin{array}{l}\text { LC in the herd } \\
\text { LC productivity }\end{array}$ & L.LC ${ }^{-1}$.day ${ }^{-1}$ & $\begin{array}{l}\text { Number of lactation cows in relation to total } \\
\text { animals in the herd (including both breeding } \\
\text { and rearing animals) }\end{array}$ \\
\hline cows & L.cow in the & Average daily yield of lactation cows \\
\hline
\end{tabular}




\begin{tabular}{|l|l|l|}
\hline productivity & herd $^{-1} \cdot$ day $^{-1}$ & $\begin{array}{l}\text { the total number of cows in cattle } \\
\text { (including both breeding and rearing } \\
\text { animals) }\end{array}$ \\
\hline Land productivity & L.ha $^{-1} \cdot$ year $^{-1}$ & $\begin{array}{l}\text { Milk yield (in liters) in relation to the area } \\
\text { allocated to dairy farming }\end{array}$ \\
\cline { 2 - 4 } & LC.ha ${ }^{-1} \cdot \mathrm{year}^{-1}$ & $\begin{array}{l}\text { Lactation cows in relation to the area } \\
\text { allocated to dairy farming }\end{array}$ \\
\hline FLF productivity & L.FLF .day $^{-1}$ & $\begin{array}{l}\text { Milk yield (in liters) in relation to the } \\
\text { number of family labor force allocated to } \\
\text { dairy farming per day }\end{array}$ \\
\hline
\end{tabular}

\section{Results and Discussion}

\subsection{Land Productivity}

Zootechnical results driven by the grazing system under irrigation in an intermittent stocking, shown in Table 1, indicated that the module of 0.86 ha of Mombaça grass made it possible to achieve a significant stocking rate, ranging from 16 to 23 animal units (AU) per hectare. The average daily milk yield ranged from 189 to 302 liters, resulting in a productivity that varied from 219 to 349 liters of milk per hectare per day. Moreover, the substantial supplementation carried out for 106 days, along the dry season 2013, resulted in a 70-day reduction, approximately, in comparison with the conventional system adopted in the region. These results support information given by Mendonça \& Camargo (2009), who pointed out that pasture irrigation reduces the effects of climate stress and allows the recovering of its high productivity earlier in the transition from winter to spring.

Table 1 . Stocking rate, average daily milk yield and average daily productivity by month of the intensified area in Mombaça grass in 2013

Jan. Feb. Mar. Apr. May Jun. Jul. Aug. Sep. Oct. Nov. Dec.

\begin{tabular}{lccccccccccccc}
\hline AU.ha $^{-1}$ & 16 & 20 & 20 & 20 & 16 & 17 & 18 & 18 & 20 & 20 & 23 & 16 \\
$\begin{array}{l}\text { Daily milk } \\
\text { yield }\end{array}$ & 198 & 266 & 226 & 218 & 196 & 189 & 195 & 242 & 258 & 252 & 302 & 268 \\
& & & & & & & & & & & & \\
L.ha . day $^{-1}$ & 230 & 309 & 309 & 253 & 228 & 219 & 227 & 281 & 300 & 293 & 349 & 312
\end{tabular}

Source: Research data.

As such, the intermittent stocking management led to a $50 \%$ reduction in the total area allocated to dairy farming and a $90 \%$ increase in the milk yield. 


\subsection{Importance of Production Scale}

The search for a production scale, however, is a preponderant factor in keeping a viable milk production system as, in addition to the volume produced is directly related to the income earned in the activity, it is also the item over which, proportionally, and the farmer has the greatest capacity for influence when compared to the price of the milk. When analyzed economic forecasts on dairy farms in FF as strategic tools for evaluating livestock development, Bassotto et al. (2018) found that the milk yield is responsible for maintaining profitability, providing the long-term continuity of productive activities.

\subsection{Zootechnical Performance Indicators}

Table 2 shows the evolution of the main zootechnical indicators in the two productive cycles. The indicator that assesses reproductive efficiency, measured by the proportion of LC in relation to the total number of cows, was negatively affected by the sale of six cows due to commercial opportunity. If they had been counted, it would have caused this indicator to exceed $80 \%$. This suggests that the reproductive efficiency of the dairy herd would be the same as the proposed by Bergamaschi et al. (2010), who affirmed a reproductively efficient dairy herd in Brazil should contain, on average, $83 \%$ of LC, with a 10-month lactation period, which would mean a herd with 12 months of calving interval.

Table 2. Zootechnical performance indicators of family dairy production, located in the municipality of Alegre, south of the state of Espírito Santo, in two production cycles

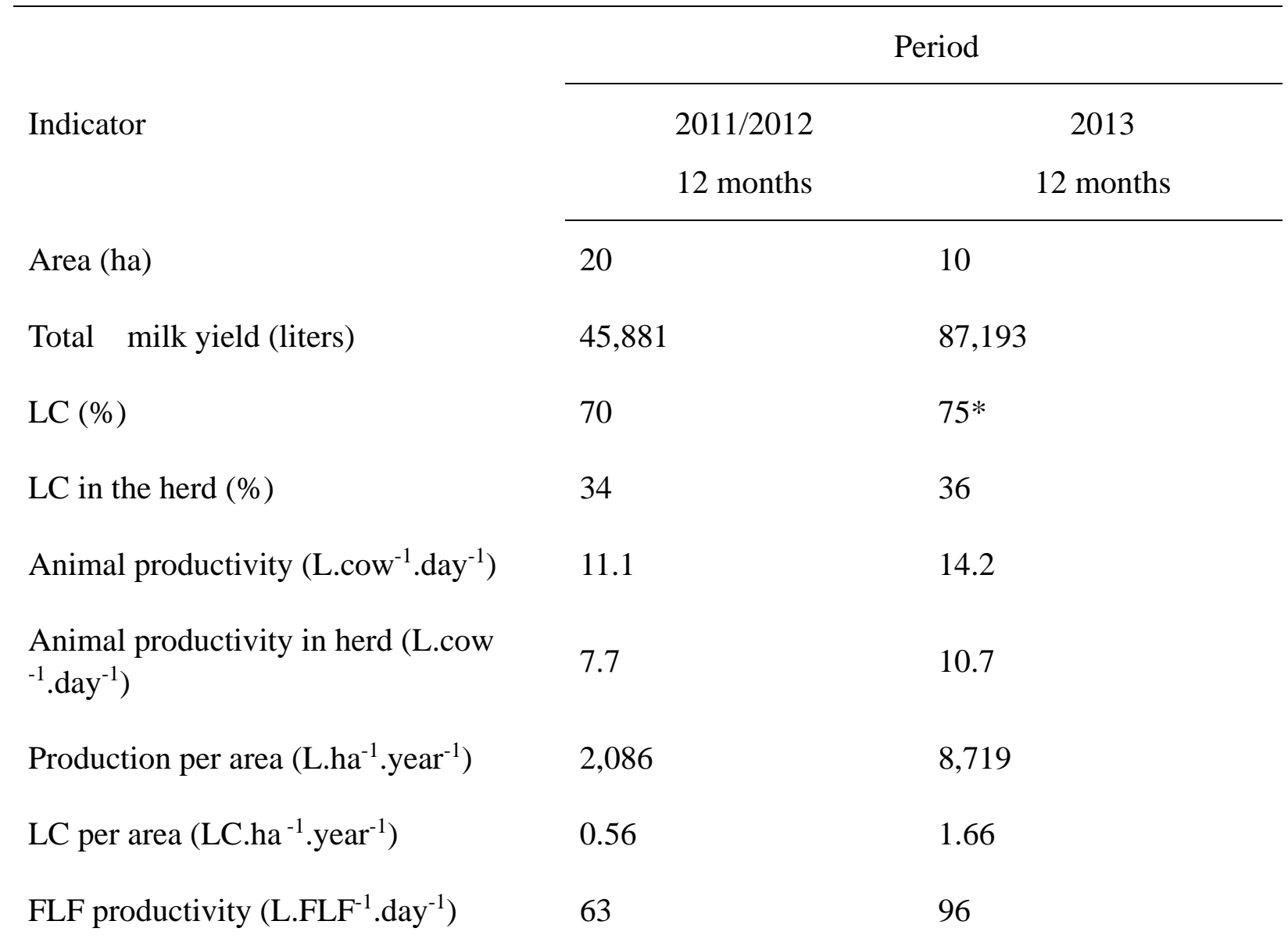


*Recorded the sale of six cows.

Source: Prepared by the authors using data from the research.

Animal productivity increased approximately $28 \%$, although it is noticed the difference between animal productivity expressed in liters per lactation cow per day (LC) and animal productivity expressed in liters per cow of the herd per day (LC in herd) is approximately $6 \%$ smaller after the intensification process, which suggests an advance in the herd structure breeding, reflecting the increase in the number of LC in the herd, which achieved $36 \%$. The value expected for this indicator is between 40 and 60\% (CAMILO NETO et al., 2012), which would be achievable in the farm studied if there had been no sale of cows.

Performance indicators of land productivity measured by milk production and the number of dairy cows per area presented a substantial increase in land occupation efficiency. When analyzing land productivity by milk yield, an increase of $318 \%$ was seen, reaching a value above the average of 3,333 L.ha- ${ }^{-1}$.year ${ }^{-1}$ estimated in 159 dairy farms studied by Pereira et al. (2016) in the Alto Paranaíba region, state of Minas Gerais, Brazil. As Costa (2007) stated, this indicator should exceed 7,300 L.ha' ${ }^{-1}$ year $^{-1}$.

In this study, the decrease in land occupation combined with the increase in the number of LC resulted in 1.66 lactation cow per hectare $\left(\mathrm{LC}^{-} \mathrm{ha}^{1}\right)$, a value higher than 0.70 LC.ha $^{-1}$ reported by Pereira et al. (2016), and higher than 1.18 LC.ha $^{-1}$ found by Bassotto et al. (2018). These authors confirmed that the results obtained in that study were satisfactory for the number of LC per area.

According to Lima et al. (2012), pasture milk production systems adopting technologies such as irrigation and forage conservation bring the benefits from lower production costs, due to reduced expenses with facilities, machinery, and labor force (LF). In the current study, however, which adopted a similar production system, the productivity of LF was only 96 L.LF ${ }^{-1}$.day ${ }^{-1}$. As a comparison, the productivity of LF in a study carried out by Camilo Neto et al. (2012) ranged from 126.16 to $562.03 \mathrm{~L} . L F^{-1}$.day ${ }^{-1}$ according to the technology employed, just as the 876.6 L. LF ${ }^{-1}$.day ${ }^{-1}$ found by Lima et al. (2012).

\subsection{Labor Productivity}

LF productivity is an indicator to evaluate human resource efficiency, considered by Lima et al. (2012) as being dependent on the herd productivity and favorable conditions for work. Hence, in this study, the low scale of production can explain the low level of this indicator; as such, it is essential that the strategic planning of activities determine working conditions that promote worker comfort by means of technologies accessible to the FF.

\subsection{Globalized Context}

Structural adjustment processes have enabled some developing countries to benefit more directly from their national and regional comparative advantages. However, as sectoral efficiency is still vulnerable, the need for learning about the dynamics of the agricultural sector in a globalized context has arisen (FINAMORE et al., 2017). 
In this way, New Zealand has the largest dairy processor in the world and is part of the world's largest dairy marketing company to significantly influence the prices of global dairy products and, consequently, the prices paid for raw materials in producing countries (CAMILO, 2019). As DairyNZ \& LIC stated (2018), the family business model, which combines land and herd ownership, as well as management control, leads $60 \%$ of New Zealand dairy herd, in which $43 \%$ of the farms have from 150 to 349 animals with an average lactation above 4,000 liters, which demonstrates the efficient use of its LF. As in Brazil, this scenario in New Zealand is typical of a worldwide historical trend of exclusion of inefficient dairy farmers and continuous search for efficiency and production scale. But it also suggests a limited expansion of dairy production of a relevant country in the international market, differently from Brazil, which has wide technical conditions to increase its production and become competitive at a global level.

In this sense, this study is in line with Reis et al. (2017), who affirmed that the knowledgeable use of management tools can assist farmers to identify strengths and weaknesses of rural properties, providing rapid decisions with the aim, respectively, of correcting failures and turn them into opportunities for economic and zootechnical gains.

\section{Conclusion}

This single case study shows that the intensification model suggested in this paper, should be a viable alternative for modernizing the Brazilian dairy family farming as long as the intermittent stocking management in irrigated tropical pasture is considered as part of a complex arrangement of productive resources, which have to be used in harmony, taking into consideration the efficiency of grazing management, herd structure, forage species adequacy, topography, and other factors.

For this reason, the viability of the dairy family farming starts from raising awareness among rural extensionists and farmers on the adoption of management models that result in the best decision making by means of farm and animal indicators.

New studies with a larger number of dairy family farms assisted by technicians need to be conducted to ensure the finds of the present single case study.

\section{Acknowledgement}

Authors are thankful to Coordenação de Aperfeiçoamento de Pessoal de Nível Superior CAPES (Higher Education Personnel Improvement Coordination), Instituto Federal de Educação, Ciência e Tecnologia do Espírito Santo - IFES (campus Alegre), and Universidade Estadual do Norte Fluminense Darcy Ribeiro - UENF for supporting this research with financial and physical resources.

\section{References}

Baccarin, J. C. (2011). Sistema de produção agropecuário brasileiro: características e evolução recente. Prefaciais_Agro.indd. Cultura Acadêmica: Universidade Estadual Paulista, Pró-Reitoria de Graduação, 2.ed. 254p. São Paulo, São Paulo. https://doi.org/10.3738/1982.2278.3229 
Bassotto, L. C., Almeida Júnior, G. A., Martins, D. T., \& Generoso, T. P. (2018). Análise técnica de uma propriedade leiteira familiar em Caldas/MG. Nucleus, 15(2), 497-505. http://dx.doi.org/10.3738/1982.2278.3229

Bergamaschi, M. A. C. M., Machado, R., \& Barbosa, R. T. (2010). Eficiência reprodutiva das vacas leiteiras. Circular Técnica 64. EMBRAPA. Available from http://www.infoteca.cnptia.embrapa.br/infoteca/handle/doc/880245

Buainain, A. M., Romeiro, A. R., \& Guanziroli, C. (2003). Family agriculture and the new rural world. Sociologias, 5(10), 312-347. https://doi.org/10.1590/S1517-45222003000200011

Camargo, A. C. (2009). Produção intensiva de leite a pasto: a geração de renda e preservação ambiental. Embrapa Pecuária Sudeste (CPPSE). NZBRASIL Genetics Info Técnico. 2(4). Available from http://ainfo.cnptia.embrapa.br/digital/bitstream/item/110012/1/ARTUR-CHINELATO-DE-C AMARGO.pdf

Camilo Neto, M., Campos, J. M. S., Oliveira, A. S., \& Gomes S. T. (2012). Identification and quantification of benchmarks of milk production systems in Minas Gerais. Revista Brasileira de Zootecnia. 41(10), 2279-2288. https://doi.org/10.1590/S1516-35982012001000020

Camilo, P. J. (2019). A internacionalização do mercado brasileiro de derivados lácteos análises sobre a atuação de oligopólios, oligopsônios e trade company. Geosul, Dossiê $\begin{array}{llll}\text { Agronegócios } \quad \text { no } & \text { Brasil, } & \text { 34(71), } & \text { 260-275. }\end{array}$ https://doi.org/10.5007/1982-5153.2019v34n71p260

Chambela Neto, A., Vieira, G. H. S., Haddade, I. R., Rosado, T. L., \& Mello, B. L. B. (2018). Aplicação de novas tecnologias na bovinocultura leiteira. In: Tendências e novas tecnologias na agropecuária. Incaper em Revista. 9, 51-65. Available from https://biblioteca.incaper.es.gov.br/digital/bitstream/123456789/3376/1/revista-incaper-v.9-ja n-dez-2018.pdf

Costa, J. L. (2007). Avaliação de indicadores técnicos de eficiência e renda da propriedade leiteira. In: Tecnologias para o desenvolvimento da pecuária de leite familiar do norte de Minas e Vale do Jequitinhonha. Embrapa Gado de Leite. p. 39-51. Available from: https://docplayer.com.br/26120690-Tecnologias-para-o-desenvolvimento-da-pecuaria-de-leite -familiar-do-norte-de-minas-e-vale-do-jequitinhonha.html

Da Silva, S. C., \& Nascimento Jr, D. (2007) Avanços na pesquisa com plantas forrageiras tropicais em pastagens: características morfofisiológicas e manejo do pastejo. Revista Brasileira de Zootecnia, 36(suppl), $\quad$ 121-138. https://doi.org/10.1590/S1516-35982007001000014

Dairy, N. Z. L. I. C. (2018). New Zealand Dairy Statistics 2017-18. Available from: www.dairynz.co.nz/dairystatistics

Finamore, E. B., Pasqual, C. A., \& Montoya, M. A. (2017). Dinâmica das fontes de crescimento da produção de leite brasileira entre 2001 e 2012: um enfoque na região de 
planejamento Corede Produção - RS. Teoria e Evidência Econômica, 23(49), 332-358. https://doi.org/10.5335/rtee.v23i49.8264

Lima, F. W. R., Oliveira, P. J. D., Pereira, E. S., Fontenele, R. M., Arruda, P. C. L., Pacheco, W. F., \& Guerreiro, A. B. (2012). Índices de produtividade e análise econômica da produção de leite a pasto no interior do Ceará. Acta Veterinaria Brasilica., 6(3),186-191.

Mendonça, F. C., \& Camargo, A. C. (2009). Uso estratégico da irrigação em sistemas de produção animal em pastagens. In: Sistemas de produção em pasto. Anais do $25^{\circ}$ Simpósio de Manejo de Pastagens. EMBRAPA Pecuária Sudeste. São Carlos, São Paulo. Available from https://ainfo.cnptia.embrapa.br/digital/bitstream/item/38693/1/PROCI-2009.00118.pdf

Oliveira, M. C., Campos, J. M. S., Oliveira, A. S., Ferreira, M. A., \& Melo, A. A. S. (2016). Benchmarks for Milk Production Systems in the Pernambuco Agreste Region, Northeastern Brazil. Rev. Caatinga., 29(3), 725-734. https://doi.org/10.1590/1983-21252016v29n324rc

Pereira, M. N., Resende, J. C., Pereira, R. A. N., \& Silva, H. C. M. (2016). Indicadores de desempenho de fazendas leiteiras de Minas Gerais. Arq. Bras. Med. Vet. Zootec., 68(4), 1033-1042. https://doi.org/10.1590/1678-4162-8218

Reis, E. M. B., Vieira, J. A., Lopes, M. A., Demeu, F. A., \& Bruhn, F. R. P. (2017). Identificação de pontos fracos e fortes associados à qualidade do leite em propriedade leiteira

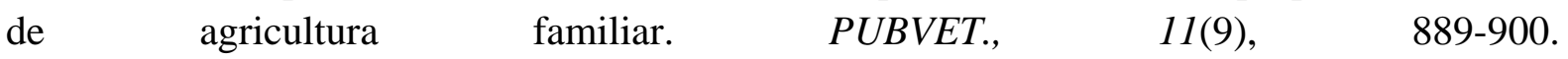
https://doi.org/10.22256/pubvet.v11n9.889-900

Resende, J. C., Carvalho, G. R., Hott, M. C., Stock, L. A. \& Oliveira, S. J. M. (2012). Níveis tecnológicos em fazendas de leite e impactos na produtividade dos fatores de produção e na rentabilidade. Panorama do Leite - Embrapa Gado de Leite., 6(65).

Riet-Correa, B., Simões, S. V. D., Pereira Filho, J. M., Azevedo, S. S., Melo, D. B., Batista, J. A., ... Riet-Correa, F. (2013). Sistemas produtivos de caprinocultura leiteira no semiárido paraibano: caracterização, principais limitantes e avaliação de estratégias de intervenção. Pesq. Vet. Bras., 33(3), 345-352. https://doi.org/10.1590/S0100-736X2013000300012

Schmoeller, R. P., Peron, V. D., De Mendonça, S. N. T. G., \& Vicenzi, S. L. (2017). Análise da prática da escrituração zootécnica e uso de sistemas de informação em 100 propriedades leiteiras do oeste do Paraná. Revista Espacios, 38(27), 23.

Silva, M. F., Pereira, J. C., Gomes, S. T., Nascif, C., \& Gomes, A. P. (2015). Avaliação dos indicadores zootécnicos e econômicos em sistemas de produção de leite. Revista de Política Agrícola, 24(1), 62-73.

\section{Copyright Disclaimer}

Copyright for this article is retained by the author(s), with first publication rights granted to the journal.

This is an open-access article distributed under the terms and conditions of the Creative Commons Attribution license (http://creativecommons.org/licenses/by/4.0/). 